\title{
Wprowadzenie
}

\section{Chwyty perswazyjne w różnych dyskursach}

Zbiór tekstów poświęconych stosowaniu różnych sposobów oddziaływania na odbiorcę otwiera ogólny zarys wyróżniania dyskursów na podstawie sposobów argumentowania, opracowany przez Aleksego Awdiejewa. Stanowi on wprowadzenie do dalszych rozważań, związanych z konkretnymi dyskursami. Wskazanie na zbieżność sposobów dowodzenia w dyskursach retorycznym i matematycznym czy fizycznym przedstawia Jakub Z. Lichański. Kolejne teksty ukazują sposoby analizy różnych komunikatów perswazyjnych od strony ich odbiorcy, a następnie od strony ich nadawcy. Taki układ przyjmujemy dlatego, że najpierw musimy rozpoznać chwyty stosowane w tekstach, żeby je powielać lub odrzucać jako nieskuteczne i w odniesieniu do nich tworzyć nowe, oryginalne, silniej wpływające na odbiorcę. Analizie perswazji i argumentacji aksjologicznej w tekstach publicystycznych poświęcone są rozważania Grażyny Habrajskiej, Piotra Lewińskiego, Elżbiety Laskowskiej, Anny Barańskiej-Szmitko i Anity Filipczak-Białkowskiej, w których autorzy prezentują różne metody badawcze. Kolejny tekst stanowi bardzo interesujące opracowanie Jolanty Antas i Michała Kozienia, demaskujący niespójność komunikatów werbalnych $\mathrm{z}$ niewerbalnymi w wypowiedziach polskich polityków. To bardzo ciekawe studium obnażające kłamstwa, niepewność, agresję itd., serwowane telewidzom i internautom. Grupę tekstów, ukazujących różne chwyty perswazyjne stosowane przez nadawców komunikatów, otwiera opracowanie Zbigniewa Nęckiego, przedstawiające perswazję z perspektywy psychologicznej. W kręgu zagadnień psychologicznych porusza się również Karolina Dobrosz-Michiewicz. Natomiast opracowania Marka Ostrowskiego, Krzysztofa Korżyka i Doroty Garbicz ukazują wybrane aspekty filozoficzne argumentacji. Ostatnią grupę tworzą teksty pokazujące chwyty perswazyjne w różnych dyskursach, bogato ilustrowane przykładami. Bardzo interesujące spostrzeżenia na temat perswazji (a może jednak manipulacji?) w rosyjskich internetowych serwisach informacyjnych prezentuje Aleksander Kiklewicz, a w polskich programach informacyjnych - Wiesław Czechowski. Na pograniczu perswazji i manipulacji sytuuje się także omówiony przez Anitę Filipczak-Białkowską mechanizm generowania luki informacyjnej. Manipulacyjny charakter mają również reklamy prezentowane w formie zwiastunów filmowych, o czym pisze Agnieszka Barczyk-Sitkowska. W kolejnych tekstach mamy pokazaną perswazję w dyskursie specjalistycznym (Krzysztof Ozga i Agnieszka Ozga) oraz w dyskursie komicznym (Wiesław Czechowski i Krzysztof Ozga).

prof. dr hab. Grażyna Habrajska kierownik konferencji 